\title{
A renaissance of Jewish studies in contemporary Germany
}

\author{
Christina von Braun
}

DOI: $10.30752 /$ nj.89060

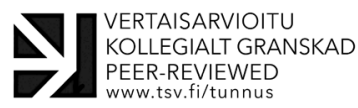

Aвstract - This paper provides an overview of the development of Jewish studies in Germany since reunification. After a brief historical review of the subject in the nineteenth century with the development of modern Reform Judaism and the science of Judaism (Wissenschaft des Judentums) created by Jewish religious and secular scholars, it focuses on the development of the past thirty years, in which not only the Jewish community but also Jewish studies have increased in importance. The growth of the Jewish community was largely due to immigration from the Soviet Union, but also partly to young Israelis who moved to Berlin. In line with these different backgrounds, a new interest in diaspora research emerged. The paper also deals with the difference between German Jewish studies (necessarily shaped by the Holocaust) and those of most other countries, where Jewish studies are mainly designed by Jewish scholars.

\section{The term 'Jewish Studies'}

The term 'Jewish studies' has a double meaning. First, it encompasses the totality of all academic disciplines dealing with the religion, culture and history of Judaism. Secondly, it refers to studies that Jews pursue as Jews. Each can, but need not, coincide with the other. There have always been times when studies of Judaism were conducted while Jews were being persecuted by the very same people. This happened both in Christian theology, where Judaic studies often served the purpose of 'christianising' the Hebrew Bible, and with National Socialism: right after the occupation of Czechoslovakia in 1938-9, Nazis began to collect Judaica from all over the 'Protectorate', while at the same time deporting and murdering Jews. This collection, described by some of the Nazis as a 'Museum for an Extinct Race', was, paradoxically, to become the basis for one of the largest collections of Judaica in Europe (Potthast 2002).

Today's Jewish studies follow a tradition that was initiated by Jews themselves in the nineteenth century, when Jewish scholars created the Wissenschaft des Judendums, the science of Judaism. The intention was to examine the Holy Texts from the perspective of their time of origin, their history of reception, literature, linguistic idiosyncrasies, non-Jewish influences, etc. It was by no means secular Jews who took this new direction - in Breslau/ Wrocław this took place within the framework of rabbinical education. But with their new thrust these scholars pursued the goal of bringing Judaism into the modern world without the danger of adapting to the surrounding Christian society. They wanted a modern Judaism, which at the same time preserved the specificities of Jewishness. It was not without reason that they saw in the Enlightenment a 
secularised Christianity - an idea that is today widely accepted in research (Taylor 2007; von Braun 2018).

With the National Socialists this new direction of Judaism came to an abrupt standstill in Germany. Yet, it spread everywhere else. The rabbis and Jewish scholars from Berlin, Breslau or Frankfurt escaping Nazism carried their new Judaism with them: to the USA, Great Britain, Latin America, South Africa and Australia, where as a consequence liberal currents of Judaism developed. Although this modern Judaism found its counter-movement in an intensified orthodoxy, in the diaspora it is becoming the majoritarian current. Things are different in Israel. (In the beginning, Zionism was a secular or even atheistic Jewish movement, but since its foundation Israeli society - and even more so the governments and the legislations they passed - has increasingly moved towards a conservative or even orthodox understanding of Judaism.)

The 'science of Judaism' was also established for another reason. At that time, the early nineteenth century, history (as a discipline) made its entrance at German universities with the implicit and often explicit 'mandate' to create the psychological basis for the idea of a 'German nation'. In Germany, the idea of nationalism first developed in academic circles before gaining a foothold among other strata of the population - and one of the means of gaining broad support for nationalism was to declare 'Jewish' a synonym for 'un-German'. The emergence of the 'science of Judaism' represented one of the attempts to counter this idea, though not in order to create Jewish nationalism - what was at stake was the idea of self-reflection concerning Judaism, but also general questions of 'identity politics' (as we would call it today). From its beginnings in Babylonian exile, where it was first formulated as a religion, Judaism was what could be called a 'culture of doubt': it did not preach fulfilment, but patient expectation. This characteristic found a new expression with the 'science of Judaism', in which religious reflection took on a secular form pertaining to the nation, social structures and power of symbolic politics.

Modern academic Jewish studies took on a good part of the traditions of the 'science of Judaism', applying scientific and neutral criteria to their subjects. Most American universities now have a chair, a department or a curriculum for Jewish studies. The European Jewish studies, gradually established since about 1980, represent a re-importing of this body of thought, which had been expelled from many parts of Europe under the Nazis, and then again under Communism. For historical reasons, Jewish studies developed differently in each country. In Great Britain, where many Jewish intellectuals escaping from the Nazis had settled, Jewish studies are similar to what is found in the USA. The same applies to the Netherlands, although today the chairs of Jewish studies created there are coming under pressure. In France, in spite of a big Jewish community, it is not Jewish studies, but rather Holocaust studies that form the core of the field. A similar focus is found in Poland; here, it is only in the last decade or so that Jewish studies have started to establish themselves. Moreover, the ample use of antisemitic clichés by the Catholic right-wing government in Poland has resulted in a lively interest in Judaism as a political counterforce among the opposition. At several conferences I have attended in Warsaw, Lublin, Cracow and Poznán, it has become evident that the same young people who today are fighting against the nationalist PIS policy, its antifeminism and homophobia, are also fighting for a better knowledge of Polish Jewish history - as if they were hoping for support for their own anti-identity struggle from the reflections inherent in Jewish studies. As one of these young people, 
an art historian from Poznán, told me: 'We used to have the wall between East and West, communism and capitalism. Now it's inside our country.' Jewish studies have become an important ally for these movements.

\section{Jewish studies in Germany}

In the course of the last thirty or forty years (starting before the fall of the Wall), Jewish studies have begun to establish themselves in Germany. Among the Germanophone academic institutions there are now twentysix universities that have created chairs or research centres for Jewish studies, including three in Austria and three in Switzerland. In Heidelberg, the Jewish University has existed since I979, a foundation of the Jewish Central Council (the federation of West German Jewish congregations). Both secular and theological contents are conveyed here; the university works closely with the University of Heidelberg, but is an autonomous institution. Research centres were established in 1966 in Hamburg (the Institute for the History of German Jews), in 1982 in Berlin (the Centre for Research on Antisemitism), in Munich (with a chair for Jewish history and culture, and a Centre for Israel Studies), and in 1995 in Leipzig (the Simon Dubnow Institute for Jewish History and Culture). In 20I2, the Centre for Jewish Studies BerlinBrandenburg, now named after the historian Selma Stern, was founded in Berlin, which was already a focus for Jewish studies, but in a decentralised manner (for a general overview, see von Braun and Brumlik 2018). With this institution, created by six universities and two other academic institutions, a platform for academic exchange within the region arose, with a graduate research centre, co-funded by the federal government and supplying funding for professorships and doctoral or postdoctoral studies in the field. The centre combines secular with theological education, just as the fathers of
'Jewish science' had imagined in the nineteenth century. In contrast to that time, it is now an integrated part of the university structure. While the School of Jewish Theology, which is located at the University of Potsdam, has a branch of theology and religious education, the larger part of the centre is oriented towards academic disciplines that are neutral in terms of creed. There are currently about fifty research projects of doctoral or post-doctoral academics under way, most of them in non-religious fields. While the University of Potsdam does offer the possibility of obtaining a master's or doctoral degree in Jewish studies, most of the other universities involved have decided to keep to the classical disciplines such as history, philosophy, sociology, literature and science of religion. The idea behind this decision is that Jewish studies offer only a few academic positions and the candidates would thus be limited in their academic career possibilities, and also that Jewish studies should not be put into a ghetto, but rather become an inherent part of each of the classical humanities.

Some students of Jewish studies pursue rabbinic or Christian theological curricula, which require both a theological and a general academic education. But the majority are students pursuing themes of Jewish studies in a secular discipline. These students, having repeatedly encountered in the course of their studies questions of German Jewish and European Jewish history and culture, have become increasingly aware of the significant Jewish contribution to the culture of the German-speaking world. Now they seek to know more.

The interest of many foreign, especially American, researchers in German history was also helpful for the development of Jewish studies. Since not only most of the texts of racist antisemitism (Richard Wagner (Wagner 1869), Houston Stewart Chamberlain (Chamberlain I899), Artur Dinter (Dinter I9I7) to name just these few), but also those 
of the Jewish Enlightenment (from Abraham Geiger (Geiger 1865-77) to Herman Cohen (Cohen 1977, vol. II) were written in German, many scholars decided to learn the language: they wanted to be able to read the original texts. Later, this interest in the German language and culture was to benefit the exchange with research abroad and the development of Jewish studies in Germany.

\section{The experience of diaspora}

Even before the fall of the Berlin Wall - and all the more so since - a shift in attention was observed in Germany, both in the public sphere and in research: while until the I980s the main interest was in the 'dialogue' between Judaism and Christianity - a dialogue that was largely conducted by the churches and centred around an insurmountable silence - since the I99os new perspectives have emerged, among them those pertaining to the idea of a diasporic existence. It is the consequence of recent waves of migration that Germany has experienced since that time, with Eastern European and Russian immigration taking place already in the late i98os. Today, it turns out to be of ever greater relevance.

How is it possible - this is a recurring question - for a culture to endure for so long and against so many adversities and persecutions, and this in spite of dispersal? It is becoming increasingly clear that there are two answers to this question, whose self-contradiction is only apparent. One is the persistence of a religious-cultural concept, the other a high degree of flexibility that has allowed Jewish traditions and teachings to adapt time and again to current historical circumstances and cultural contexts.

In Jewish history there have been great disputes over the question of whether diaspora signifies a blessing or disaster for Jewish life. Some Jews have regarded it as God's punishment. By contrast, the great scholar Rashi
(IO4O-IIO5), who wrote the most important commentary of the Middle Ages on Tanach and Talmud, saw it as a chance for survival: a scattered people could not be annihilated with one blow (a confidence that was to prove true in the Holocaust). Others understood dispersal as an opportunity to carry the idea of monotheism out into the world, and this possibility was indeed contained in the original sense of the Greek word diaspora which means to 'to sow', 'to distribute the seed' (it was used for the first time in the Septuagint, the Greek translation of the Bible; Dufois 20I6). The Russian historian Simon Dubnow (1860-I94I), who at the beginning of the twentieth century wrote a world history of the Jewish people, was one of the first to take up a third idea: in a I93I article on the subject of diaspora (Dubnow I93I), he described its effects as the 'cultural ferment and progressive force' of a society. After centuries of studying the consequences of the diaspora for Judaism, he turned the perspective around and asked about the significance and benefits it had for the host countries. The fact that he wrote this essay at a time when Zionism had already grown to become an important political movement also points to a change in the inner Jewish debate about the classification of diaspora.

What Dubnow did not address was the fact that the 'ferment' of diaspora also had an effect on Judaism itself. The community derived its power of renewal not in the least from dispersal and the necessity of a permanent updating of laws and the self-reflection this implied. Hence diaspora explains the long survival of Jewish culture at least as much as the 'portative fatherland' of the Torah, as Heinrich Heine (Heine 1995, IV, 483) called the Holy Scripture: Judaism was preserved not only despite, but also because of dispersal. There is no other religious or cultural community in the world that has such a long and varied experience of the hardships and fears of migration, as well as of the 
enrichment it brings. Already during the exile in Babylon, from the sixth century BC, Judaism developed guidelines and a great narrative the stories of the Bible, above all Exodus - in order to live not only in but also with foreign cultures. These strategies became the prerequisite for something as paradoxical as a migratory homeland. Today, when 65 million people worldwide are on the run or live in migration contexts, the experience of the diaspora and the skills Jews acquired in the process could become groundbreaking for other cultures. Over the last two and a half thousand years, Jewish communities have shown how to preserve one's own within the other. It is in this sense that Jewish studies have today become a model both for political activism and university research dealing with migration, stereotyping, minority protection and intercultural interdependence. At the Selma Stern Centre for Jewish studies, this question has become a core topic of our research.

\section{Jewish studies in Germany in light of the Shoah}

Since the fall of the Berlin Wall, a question that was taboo until the early I980s has also been addressed. The question is: what does it mean to pursue Jewish studies in Germany, in view of the civilisational breakdown caused by the Shoah? It means first of all that in the country of the perpetrators the word 'Jewish' can hardly be conceptualised without the term 'Shoah'. Whether it is explicitly addressed or not, the Holocaust always forms the implicit background to research in Jewish studies in Germany. It may not be inherent in a particular research topic, but it is inscribed in the thinking and psyche of the researcher. In this respect, the Jewish studies of the Germanspeaking world have a dimension of reflection on the German past that is closely linked to the question of the collective self. This reflection is in turn combined with the reflection that is characteristic of Jewish traditions themselves. This is what makes Jewish studies in Germany so specific: that the self-doubts associated with the inheritance of National Socialism find a counterpart in the self-reflection transported by Jewish studies themselves. This results in completely different perspectives and research fields from those of Jewish studies in other countries.

\section{Jewish studies and non-Jews}

In most other countries Jewish studies attract mainly researchers who consider themselves to be Jewish (be it in a religious or cultural form). For this reason prominent scholars such as Aaron Hughes (Hughes 20I3) have warned that Jewish studies run the risk of becoming an academic field serving self-affirmation and identity politics comparable to that of 'ethnic minorities' and Afro-American studies.

In Germany, by contrast, there are many researchers who do not come from a Jewish background. This is, of course, the consequence of the expulsion and annihilation of Jewish life in Germany. Among the non-Jewish academics of Jewish studies in Germany, some, especially those in theology, opt for conversion (by which they detach themselves from their previous context and turn to religious Judaism). Most, however, do not take this step and tend to look for ways of combining Jewish self-reflection with a reflection on their non-Jewish inheritance as children of the perpetrators. In the USA there is also a high number of converts: according to a recent Pew report (May 2015), every sixth citizen who professes Judaism is a convert. (Of these, according to the same Pew report, 44 per cent belong to reform Judaism, 22 per cent to conservative Judaism, I4 per cent are orthodox, 5 per cent belong to other movements, 16 per cent do not identify with any specific movement of Judaism.) But in the USA conversion to Judaism is usually based on completely different motives: it takes place 
for instance because the spouse is Jewish, or to compensate for the fact that the father (but not the mother) are Jews. The consequence of this is that Jewish studies in the USA have become a predominantly 'Jewish affair' - a development that is also attributed to the fact that a number of chairs are funded with this aim of creating specific identities. This meanwhile leads to criticism from Jewish scholars themselves (e.g. Hughes 20I3).

Such debates do not exist in German Jewish studies, but the question of whether gentiles should have the right to interpret Jewish phenomena has been increasingly addressed in recent times. The growing strength of this debate in recent years is due to the fact that more Jews are now living in Germany and are also represented in Jewish studies as researchers and teachers: they claim that phenomena of Jewish religion, culture or history should be viewed from an inner Jewish perspective. This is understandable, especially in view of German history, and partly corresponds to what the 'science of Judaism' intended. However, the scholars of the nineteenth century had to situate their research outside the general university context, and it was precisely this that they criticised. They wanted Judaism to be a topic of study for all sciences, and hence to be of interest not merely for scholars of Jewish origin. Their wish was not feasible at that time - in the antisemitic German universities there was already a high opposition to appointing Jews within classical fields, and to create Jewish studies as a field in its own right met with complete rejection. That is a difference from German academic life in the twenty-first century.

\section{Jewish studies and Christianity}

The idea of a specifically Jewish interpretation of Jewish religion and culture can also be looked at from another perspective: Jewish scholars have contributed to some of the most important research on Christianity in recent decades. One could mention the medievalist Ernst Kantorowicz (Kantorowicz 1957), who described the transfer of the Christological idea of the 'two natures of Christ' from religion to the secular definition of European royalty. Or Miri Rubin (Rubin I99I), who wrote the most important study on the symbolism of the host, and the art historian Leo Steinberg (Steinberg 1996), who made visible the role of sexual images in the depictions of the crucifixion. Also, David Biale (Biale 2007) has compared the blood metaphors in Judaism and Christianity. To exclude the research of these great academics on the grounds that they lack a Christian background would imply a great loss of knowledge and would be pure Christian identity politics. By the same token, these examples show that Jewish studies could also benefit from a non-Jewish external perspective. However, it is difficult to deny that Jewish identity in Germany - especially since the Shoah - cannot look back like Christianity upon an identity approved by the majority over the centuries and thus become part of academic taken-for-grantedness. It is therefore more than understandable that Jewish studies, quite apart from contributing to selfreflection, do also want to contribute to the building of a specific Jewish identity.

\section{The renaissance of Jewish Life and shift- ing questions within Jewish studies}

Since the fall of the Berlin Wall, two phenomena have been observed in Germany: one is a renaissance of Jewish life, the other is the shifting of questions within Jewish studies. I would like to conclude by giving some details on these points. To put it in a nutshell: since I989 there have been fewer and fewer communists in Germany, but there are more and more Russians! They are of vital importance for Jewish life and Jewish studies. 
Let me recapitulate briefly. The members of the Jewish communities that established themselves in the Federal Republic after 1945 were mostly displaced persons from Romania, Czechoslovakia, Hungary and above all Poland: they had fled to the West from the pogroms of the post-war period and then formed the core of new Jewish communities in Germany - a country where nobody could imagine Jewish life would ever arise again. There was also a Jewish community in the GDR; it often consisted of Jewish intellectuals and resistance fighters who had returned from emigration after the war and decided in favour of Communist Germany. However, most of these intellectuals did not want to have anything to do with religious Judaism - sometimes not even with secular Judaism. I met several people born of Jewish parents in the GDR who were not informed by their parents that they were of Jewish origin. They often only found out as adults. (The same phenomenon is encountered in other Communist countries such as Poland, Hungary or Romania.)

In the period $1972-89$ several thousand Soviet Jews came via Vienna to Germany, especially to Berlin. When Gorbachev lifted the exit restrictions in 1985 , more Jews emigrated to Israel and the USA, and a few to Germany. The Jewish communities in West Germany at that time comprised 27,000-29,000 Jews, while the Jewish community of the GDR was estimated at 500 persons. But then immigration intensified, even before the fall of the Berlin Wall, especially to the GDR. In 1990 an entry ban was introduced, which was, however, lifted again for Jews in I99I by an all-German parliamentary decision. The institution of the so-called 'contingent refugee' was created: those concerned did not have to go through the usual asylum application procedures. A proof of Jewish descent was sufficient to settle in Germany.

'Jewish' was defined as someone who had at least one Jewish parent. This, of course, also included the descendants of Jewish fathers, which created conflicts with the existing Jewish communities living according to the halakhic matrilineal law. The imbalance was reinforced by the fact that many Soviet identity documents only mentioned the ethnic or religious affiliation of the father. Between I991 and 2004 a total of 220,000 Jewish immigrants, including their relatives, came to Germany from the former Soviet Union. In 2004, the number of Jewish immigrants to Germany exceeded that of immigrants to Israel. About half of the immigrants saw themselves as religious and registered in the congregations: almost IO०,000 in I05 congregations. Germany thus formed the third largest Jewish community in Europe; the largest of these congregations was in Berlin (almost Io, ooo members). More than half of the immigrants from the former USSR (approx. 150,000) did not join any Jewish religious congregation. Today, Russian Jewish immigration accounts for 95 per cent of Jews in Germany.

This development has been reinforced in the last ten years by the fact that more and more young people from Israel are moving to Berlin. At the end of 2014 there were about 4000 Israelis living in Berlin. But there were also many who did not register at the embassy because, thanks to a European second passport, they were able to enter freely. Conservative estimates today are based on I2,000-I5,000 Israelis who have settled in Berlin.

It is not necessarily Germany as such that attracts them, but rather the capital, with its long history of migration, which over at least two centuries has repeatedly made it a hub of cultures. Since r8oo Berlin was constantly growing - between I87I and I9I4 alone, the population quadrupled from about 800,000 to 3.5 million. At the same time Berlin also became a place of cultural exchange: this began in the eighteenth century with the Huguenots, whom the Prussian Great Elector 
had offered asylum from French persecution of Protestantism, while at the same time hoping that the Huguenots would give Prussia a boost in modernisation. Later, immigrants from Silesia, Eastern Europe, the Baltic States and Russia joined. Among each of these waves of immigration there were many Jews, especially when pogroms occurred in the tsarist empire. Today there is hardly a citizen of Berlin who can look back on a family residence of three generations or more. For Jews, as symbolic figures of migration, this melting pot became a familiar terrain - and it is precisely this that the young Israelis are still seeking today: one could say that their concern is the diasporic experience. A number of them are also investigating the German or Polish roots of their grandparents and great-grandparents.

This development had a considerable influence on Jewish studies. Many immigrants from the Soviet Union began to be acquainted with their Judaism once they arrived in Germany. In the congregations, they appropriated the rituals they had not practised within their families. They found a new home in religion, giving them a feeling of security. Others, not interested in religion or excluded from the religious communities for halakhic reasons, began to explore their Judaism in a secular way. They immersed themselves in the history, literary texts and biographies of Jews who had shaped the cultural life of Europe. Hermann Simon, the former director of the Centrum Judaicum, a Jewish cultural institution with which we cooperate intensely, told me on the occasion of the foundation of the Selma Stern Centre: 'We need this academic institution just for the fact that these immigrants from Russia have no or little knowledge of Jewish history'. Today there are also thirteen Jewish schools in Germany. Most of them were founded after the reunification. The students are by no means all Jewish. At the Berlin Moses Mendelssohn Gymnasium with its 450 students, 60 to 65 per cent of the students are Jewish, while the rest are not. The school does not require observance.

In order to meet the need for growing spiritual care, the rabbinical training was expanded: in addition to the university in Heidelberg, conservative and liberal training centres emerged. The Abraham Geiger Kolleg, where the education of liberal rabbis takes place, had already been founded in 1999, but in 2013 it became part of the BerlinBrandenburg Centre for Jewish Studies, and in this context received considerable funding from the federal government. In Potsdam a chair for Jewish theology, and at the musical academy (Musikhochschule) in Weimar a professorship for Jewish music and cantoral training were founded. At the same time, the Zacharias Frankel Kolleg for conservative rabbinical education was created, also in Potsdam. The appointments to the chairs are supported by an advisory committee of rabbis. In 2006, the first rabbi ordination in Germany since the Second World War took place in Dresden. Orthodox rabbinic education also flourished, often funded by the Ronald Lauder Foundation. It takes place outside the academic context, in religious institutions.

The interests of non-religious Jews were equally taken into account. The Ernst Ludwig Ehrlich Studienwerk was founded in 2009: it awards three hundred scholarships to particularly talented Jewish students and doctoral candidates. Since its foundation, almost six hundred scholarship holders have benefited; over 90 per cent of them have a migration background. A few of them pursue rabbinical education, but most of them enrol in the secular study or graduate programmes of Jewish studies, and still others study classical subjects such as medicine or social sciences. As part of the structured programme, however, they all receive introductions to Jewish life. In addition, exchange takes place between them, which is important for many students with a migrant background. 


\section{Jewish studies and identity-structuring}

With these developments, over the last ten to twenty years, Jewish studies in Germany have gradually tended to become an identitystructuring programme. And yet, this potential homogenisation effect is countered by a decisive factor: the different migration backgrounds of the various participants. In a recent publication, some of these scholars tell their life stories. All of them are between twenty-five and thirty-five years old. Their descriptions are helpful because they are not sociological analyses of the 'object', but the self-representations of these young Jews. To give a few examples (cf. Belkin 20I7):

- Greta Zelener, born in Odessa, came to Germany with her parents when she was five years old. She is now studying adult education because she wants to help people who, like her parents, had to start from scratch in a new country. She only acquired her Judaism at school in Germany. She belongs to the first generation of her family, which 'lives again in Germany, speaks German and has anew the privilege of being able to take advantage of offers of Jewish life' (ibid., I8). Her great-grandmother lived in BerlinCharlottenburg and was a survivor of the Shoah.

- Lea Simon was born shortly before the fall of the wall in Berlin and grew up in a tradition-conscious Jewish family. She is writing a doctoral thesis on composers in the kibbutzim in Israel.

- Marina Rudman comes from Saint Petersburg and found an initial approach to her Jewish origins in Germany: she attended a strictly religious girls' school in Berlin, founded by the Ronald Lauder Foundation, and then studied in Jena, where there was only one tiny Jewish community. On discovering this, she founded a Jewish student association. She studies economy of health.
- Meytal Rozental comes from Israel, while her ancestors were from Romania and Hungary, where her mother witnessed the arrival of the Russian tanks in 1956. She had been accepted for the master's study programme at the Hebrew University and decided to go to Berlin for a few days before the beginning of the semester. Once there she decided to stay in Berlin and now lives in Neukölln. Like many Israelis she has a European passport, in her case Hungarian. Meytal has completed her studies in migration and ethnicity and is committed to working with refugees. 'In my circle of friends', she says, 'there are people from Italy, the USA and Germany, but also Palestine, Syria, Egypt - people with whom I had no contact before, because I was not allowed to have any contact' (ibid., 29).

- Anastassia Pletoukhina and Valentin Lutset came from Moscow and Saint Petersburg. Anastassia came to Germany with her family in the early i99os. Her grandfather has been a prayer leader in the synagogue of Lübeck for twenty years; after emigration he was finally able to live his Judaism. In the community, Anastassia suddenly understood that 'many of the unusual family traditions were not only cultivated with us privately, but belonged to something greater' (ibid., I2). She is doing her doctorate in social sciences, while her partner Valentin is studying communication design.

- The series could be continued - for example with Yan Wissmann, whose greatgrandparents had fled to Brazil from the Nazis and who is now studying political science in Berlin. Or Akiva Weingarten, who comes from an Orthodox Hasidic community in Monsey, NY, where he received a strictly religious education. Secular subjects such as English, mathematics or history were only taught one hour a day. There were no natural sciences at all, no chemistry, biology or physics. After a detour via Israel, he is now training as a liberal rabbi 
at the Abraham Geiger Kolleg. He was fortunate: his family did not cut off the ties with him. I may add that Akiva decided to come to Germany for two reasons: free academic tuition, and the similarities of German and Yiddish, the language he grew up with.

All these young people define themselves as Jewish and as cosmopolitans. Most of them have two or three passports. For them, the former antisemitic accusation that Jews were 'rootless' became a positive self-definition. The only thing they have in common is that of belonging to the 'third generation', says Dimitrij Belkin (ibid., I2), who adds that with them 'a pluralising majority society meets a pluralising Jewish community'.

\section{Conclusion}

To sum up: since the Iron Curtain came down, we have experienced a renaissance of Jewish life in Germany - a country which, having been at the centre of the Cold War, may stand as an example for the changes that have come about with post-Communism in Europe. In a country in which 'according to all the rules of post-Babylonian history [...] there should have been no Jews and certainly no Jewish community any more', says Belkin, something unusual can be registered: Jews are 'no longer sitting on the legendary "packed suitcases"' (ibid., II). This does not mean that one can speak of a 'new normality'. However, the change of a linguistic figure is symptomatic: until the I990s one spoke of 'Jews in Germany'. The Shoah prohibited the previously widespread talk of 'German Jewry'. Meanwhile there is again increasing talk of 'German Jews'. This is the one side. On the other side, the unity of the Jewish community does not exist any more. It was always a myth, of course, especially in Berlin. But for younger Jews, this myth has lost its appeal, as one of them said: 'This generation no longer wants such homogeneity' (ibid., II).
Jewish studies are a direct reflection of these developments. Parallel to the renaissance of Jewish life in Germany, they experienced a renaissance, which is reflected not only in academia but also in schools. At the same time, Jewish studies accomplish a remarkable feat: on the one side, they structure identity; on the other, the students themselves contribute so many different cultural backgrounds that the diaspora of the old Jewish existence, which had formed the basis for reflection, is as present as ever.

Let me finish on one important note. What I have been describing concerns Jewish studies. It does not cover the very important issue of the new rise of antisemitism in Germany. The development is highly alarming and is, of course, beginning to have an influence on Jewish studies themselves - which means that the question of antisemitism is again moving centre stage. The scholars of the Selma Stern Centre - especially the research programmes directed by the Zentrum für Antisemitismusforschung - are reacting to this. The ZfA is the oldest institution of Jewish studies in Berlin (it was created in 1982) and has been an integral part of the Selma Stern Centre from the start. One of the explanations for modern antisemitism is certainly to be found in the repercussions German reunification has had on identity politics, especially in Eastern Germany. But that is just one aspect. The research of the ZfA is now focusing on antisemitism in social media - an aspect that plays an important role in other countries too where the new right is on the rise. It would need a paper of its own, however, to describe and analyse the recent developments of antisemitism.

\section{References}

Belkin, Dimitrij, 2017. 'Positive jüdische Geschichte: Babel 21. Ein Diaspora-Update', in Belkin (ed.), 2017 .

- (ed.), 2017. \#Babel 2I, Migration und Jüdische Gemeinschaft (Berlin, Hentrich \& Hentrich). 
Biale, David, 2007). Blood and Belief. The Circulation of a Symbol between Jews and Christians (Berkeley, University of California Press).

Braun, Christina von, 2018. Blutsbande. Verwandtschaft als Kulturgeschichte (Berlin, Aufbau).

Braun, Christina von, and Micha Brumlik (eds.), 2018. Handbuch Jüdische Studien (Köln \& New York, Böhlau).

Chamberlain, Houston Stewart, I899. Die Grundlagen des XIX. Jahrbunderts (München, Bruckmann).

Cohen, Hermann, 1977. 'Religion der Vernunft aus den Quellen des Judentums', in: Werke, ed. by Hermann-Cohen-Archiv am Philosophischen Seminar der Universität Zürich unter der Leitung von Helmut Holzhey, Bd. II (Hildesheim, Olms).

Dinter, Artur, 1917. Die Sünde wider das Blut (Leipzig, Matthes und Thost).

Dubnow, Simon, 1931. 'Diaspora', in Encyclopaedia of the Social Sciences, ed. Edwin R. A. Seligma and Alvin Johnson, vol.5, pp. 126-30 (New York, Macmillan).

Dufoix, Stéphane, 2016. The Dispersion: A History of the Word Diaspora (Leiden, Brill).

Geiger, Abraham, 1865-7r. 'Das Judenthum und seine Geschichte von der Zerstörung des zweiten Tempels bis zum Ende des zwölften Jahrhunderts', in Zwölf Vorlesungen, Bd. II (Breslau, Schletter).

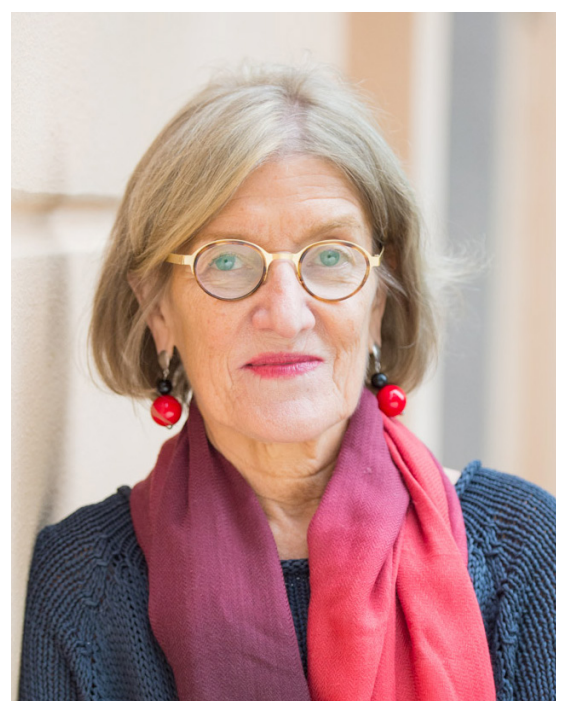

Heine, Heinrich, 1995. In: Sämtliche Schriften (München, Deutscher Taschenbuch Verlag).

Hughes, Aaron, 2013. The Study of Judaism: Authenticity, Identity, Scholarship (New York, SUNY Press).

Kantorowicz, Ernst H., 1957. The King's Two Bodies. A Study in Medieval Political Theology (Princeton, Princeton University Press).

Pew Report: <https://www.pewforum.org/2015/ 05/12/chapter-2-religious-switchingand-intermarriage/> A summary in Drew Himmelstein, ' $I$ in 6 American Jews are converts and 9 other findings in Pew study', in Jewish News of Northern California, I5 May 2015 <https://www.jweekly.com/2015/05/15/>

Potthast,Jan Björn, 2002. Dasjüdische Zentralmuseum der SS in Prag: Gegnerforscbung und Volkermord im Nationalsozialismus (Frankfurt \& New York, Campus).

Rubin, Miri, 1991. Corpus Christi. The Eucharist in Late Medieval Culture (Cambridge, Cambridge University Press).

Steinberg, Leo, 1996. The Sexuality of Christ in Renaissance Art and in Modern Oblivion, 2nd enlarged edition (Chicago \& London, University of Chicago Press).

Taylor, Charles, 2007. A Secular Age (Boston, MA, Harvard University Press).

Wagner, Richard, 1869. Das Judenthum in der Musik (Leipzig, Verlagsbuchhandlung J. J. Weber).

Christina von Braun is a writer, film-maker and professor of cultural theory and history. She was nominated full professor at Humboldt University in 1994. Before this, she worked as a freelance writer and film-maker in New York, Paris and Bonn, authoring more than fifty films and many books. She was for many years director of the Department of Gender Studies at Humboldt University, and in 2012 became the speaker of the newly established Centre for Jewish Studies BerlinBrandenburg <www.selma-stern-zentrum.de $>$. Her fields of research comprise gender, the history of writing, religion and modernity and the history of antisemitism. In 2013 she was awarded the Sigmund Freud Prize of the German Psychoanalytical Association. Home page: <http://www.christinavonbraun.de> 